\title{
Evaluasi Kelayakan Struktur Gedung Tinggi Yang Terbengkalai Selama 15 Tahun Terhadap Gempa Berdasarkan SNI 1726 - 2012
}

\author{
Afif Navir Refani1, Muhammad Sigit Darmawan1, Mudji Irmawan2 \\ 1Jurusan Diploma Tenik Sipil, Fakultas Teknik Sipil dan Perencenanaan, Institut Teknologi Sepuluh Nopember \\ 2Jurusan Teknik Sipil, Fakultas Teknik Sipil dan Perencenanaan, Institut Teknologi Sepuluh Nopember (ITS) \\ Surabaya Jl. Arif Rahman Hakim, Sukolilo, Surabaya Indonesia \\ Navir.afif@gmail.com
}

\begin{abstract}
Abstrak
Gedung tinggi di Indonesia khususnya di Surabaya sudah dimulai pembangunannya sejak tahun 90an. Namun dikarenakan terjadi krisis moneter pada tahun 1998 membuat beberapa gedung tinggi di Surabaya menjadi terbengkalai penyelesaiannya. Salah satunya adalah Gedung Apartemen Crystal Garden di Jl. Embong Malang Surabaya yang memiliki 26 lantai. Dan saat ini gedung tersebut akan dimanfaatkan kembali sebagai hunian dan pusat perbelanjaan. Untuk dapat merealisasikan rencana pemanfaatan kembali suatu gedung tinggi, maka diperlukan suatu evaluasi kelayakan pada gedung tersebut terhadap gempa berdasarkan peraturan SNI 17262012. Dalam menentukan kelayakan suatu bangunan ditentukan dari parameter kualitas material gedung saat ini dan dari parameter respons struktur terhadap beban gempa. Untuk mengukur kualitas material dibutuhkan serangkaian pengujian struktur beton bertulang. Hasil yang diharapkan adalah dapat diketahui kelayakan bangunan dari segi kualitas material beton bertulang dan dari segi respons struktur gedung terhadap gempa yang akan dibandingkan dengan peraturan terkait yang berlaku di Indonesia.
\end{abstract}

Kata kunci: kelayakan, bangunan tinggi, terbengkalai 15 tahun

\section{PENDAhULUAN}

Gedung tinggi di Indonesia khususnya di Surabaya sudah dimulai pembangunannya sejak tahun 90an. Namun dikarenakan terjadi krisis moneter pada tahun 1998 membuat beberapa gedung tinggi di Surabaya menjadi terbengkalai penyelesaiannya. Salah satunya adalah Gedung Apartemen Crystal Garden di Jl. Embong Malang Surabaya yang memiliki 26 lantai. Dan saat ini gedung tersebut akan dimanfaatkan kembali sebagai hunian dan pusat perbelanjaan. Untuk dapat merealisasikan rencana pemanfaatan kembali suatu gedung tinggi, maka diperlukan suatu evaluasi kelayakan pada gedung tersebut terhadap gempa berdasarkan peraturan SNI 17262012.

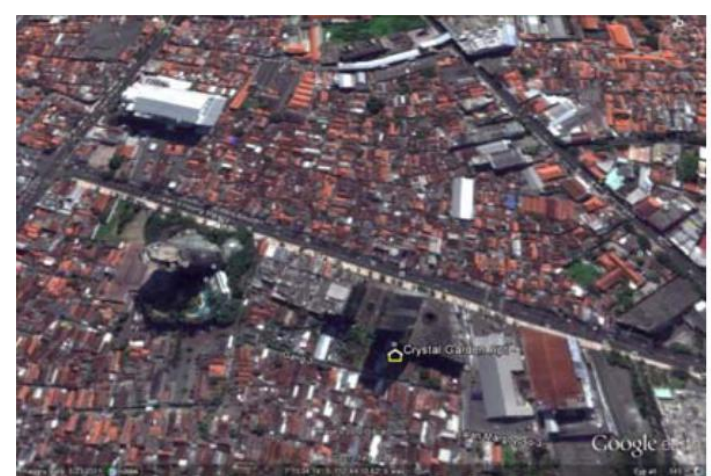

(a)

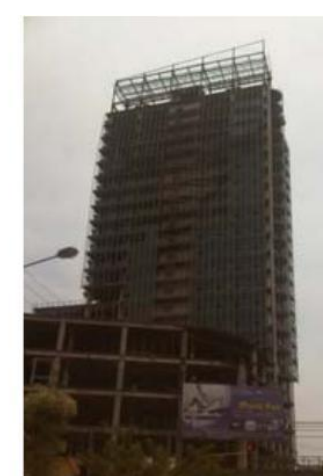

(b)

Gambar 1. (a) Lokasi Gedung Crystal Garden; (b) Tampak Bangunan Crystal Garden

Pada bangunan gedung beton bertulang yang terbengkalai tanpa ada perawatan sama sekali selama kurang lebih 15 tahun, adanya dua standar bangunan beton bertulang untuk gedung tinggi yang baru yaitu SNI-1726 -2012 dan SNI-28472013 menyebabkan bangunan struktur beton bertulang tersebut perlu dievaluasi kembali kelayakannya. Hal ini disebabkan karena perencanaan bangunan pada saat 15 tahun yang lalu belum memperhatikan beberapa faktor yang lebih detail seperti pada saat ini. Selain itu penelitian mengenai evaluasi bangunan eksisting yang terbengkalai terhadap gempa belum banyak. Evaluasi kondisi eksisting bangunan beton bertulang bedasarkan SNI telah dilakukan oleh [1]-[5]. Para peneliti tersebut mengevaluasi bangunan bedasarkan material eksisting dan menggunakan SNI 17262002 dan SNI 2847 2002. Evaluasi kondisi eksisting bangunan yang dilakukan para peneliti ini dilakukan pada bangunan yang telah beroperasi sehingga 
terdapat tahap penyelesaian akhir bangunan (finishing) dan terdapat kemungkinan bangunan masih dilakukan perawatan. Adapun penelitian mengenai kondisi eksisting pada gedung yang terbengkalai dengan usia 15 tahun dan didasarkan SNI gempa dan beton terbaru belum pernah dilakukan. Sehingga diperlukan suatu kajian kelayakan bangunan yang terbengkalai dengan umur 15 tahun berdasarkan standar peraturan terbaru.

Hasil yang diharapkan adalah dapat diketahui kelayakan bangunan dari segi kualitas material beton bertulang dari serangkaian pengujian yang dilakukan, serta dari segi respon struktur gedung terhadap gempa.

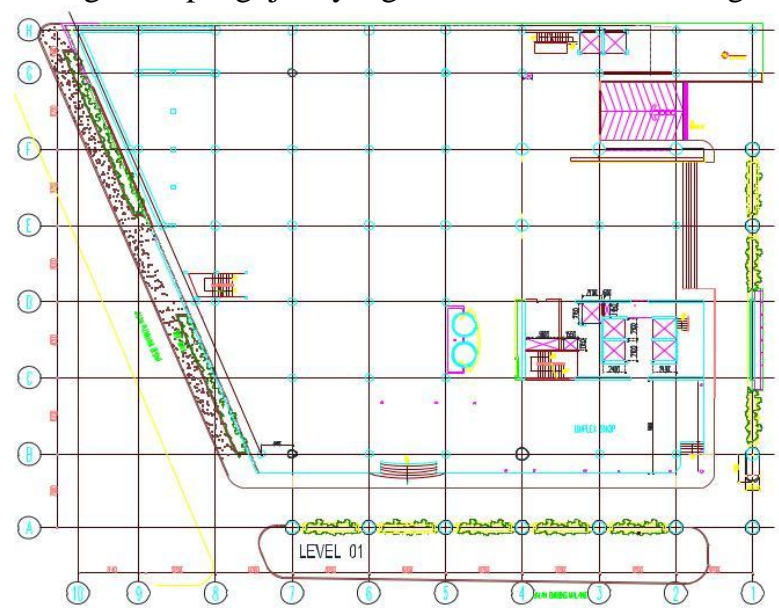

(a)

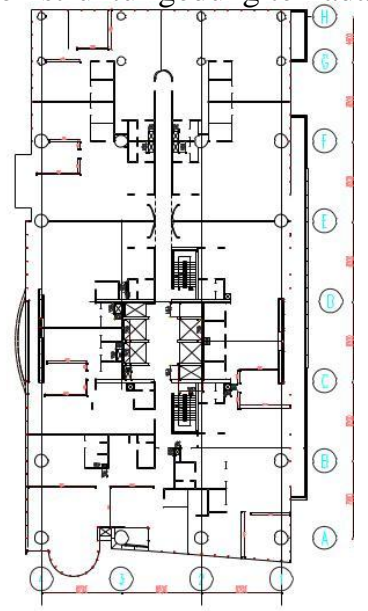

(b)

Gambar 2. (a) Denah Lantai Podium (Lantai 1 - 8) ; (b) Denah Tower (26 Lantai)

\section{TINJAUAN PUSTAKA}

Dalam menentukan kelayakan suatu bangunan ditentukan dari parameter kualitas material gedung saat ini dan dari parameter respon struktur terhadap beban gempa, dimana aturan bangunan tahan gempa yang terbaru adalah SNI 1726 2012. Untuk mengukur kualitas material dibutuhkan serangkaian pengujian yang diaplikasikan pada elemen struktur Gedung Crystal Garden sebagai obyek penelitian. Beberapa rangkaian pengujian tersebut meliputi pengujian mutu beton, kepadatan beton, kondisi jumlah tulangan terpasang, kondisi selimut beton dan kondisi potensial korosi pada elemen struktur.

\subsection{Pengujian Mutu Beton}

Pengambilan sampel bor inti beton dilakukan berdasarkan ASTM C42-90. Di mana hal ini tergolong sebagai destructive test di mana sampel diambil dengan menggunakan mata bor berdiameter 4" sehingga didapatkan sampel inti beton berdiameter $94 \mathrm{~mm}$. Adapun panjang dari sampel silinder beton setidaknya berkisar 1.9 sampai 2.1 kali diameter. Setelah itu, sampel bor inti beton akan dibuat menjadi benda uji tekan silinder. Di mana sampel berupa silinder core drill tersebut, kemudian dibawa ke laboratorium untuk dilakukan pengujian terhadap kekuatan tekan beton. Begitu pula apabila terdapat sampel baja tulangan yang ikut terambil, maka sampel tersebut nantinya akan digunakan sebagai benda uji tarik baja tulangan.

Pengujian kuat tekan di laboratorium terhadap sample silinder beton tadi dilakukan dengan alat Universal Testing Machine (UTM) 200tf. Kuat tekan dari sample silinder beton didapat dengan membagi beban tekan maksimum dengan luas permukaan tekan dari sample.

\subsection{Pengujian Kepadatan Beton}

Pengujian tingkat kerapatan beton menggunakan alat Ultrasonic Pulse Velocity (UPV) dilakukan dengan mengacu pada ketentuan ASTM C-597. Pengujian ini bertujuan untuk memeriksa kepadatan beton berdasarkan kecepatan dari gelombang ultrasonik dengan frekwensi $50 \mathrm{KHz}$. Kecepatan gelombang tersebut akan semakin cepat bila melalui beton yang kepadatannya cukup tinggi dan begitu juga sebaliknya terhadap beton yang kepadatannya kurang. Adapun pengukuran dilakukan dengan cara tidak langsung (indirect) di mana posisi transmitter dan receiver diletakkan pada bidang uji yang sama. Dari hasil test akan didapatkan kecepatan rambat gelombang ultrasonic $(\mathrm{V}, \mathrm{m} / \mathrm{s}$ ) dari setiap lokasi yang diuji dan hasilnya dibandingkan dengan klafisikasi hasil UPV menurut BS 1881-1986 (2004).

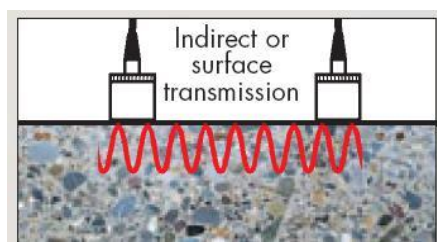

\begin{tabular}{|c|c|}
\hline Kecepatan $\mathbf{V}(\mathrm{m} / \mathrm{s})$ & Klasifikasi \\
\hline $\mathrm{V}<2130$ & Kurang \\
\hline $2130<\mathrm{V}<3060$ & Cukup \\
\hline $3060<\mathrm{V}<3670$ & Cukup Baik \\
\hline $3670<\mathrm{V}<4570$ & Baik \\
\hline $\mathrm{V}>4570$ & Baik Sekali \\
\hline
\end{tabular}




\subsection{Kondisi Jumlah Tulangan Terpasang dan Tebal Selimut Beton}

Untuk keperluan verifikasi dimensi dan penulangan elemen struktur balok, kolom dan pelat struktur Gedung Crystal Garden ini, maka diperlukan pengujian rebar detector test. Pengujian ini bertujuan untuk mencari letak penulangan yang berada didalam elemen struktur seperti balok, pelat dan kolom.

Pengukuran ini menggunakan induksi gelombang magnet yang mana pantulan gelombang dari tulangan terpasang akan menunjukkan posisi tulangan baik jarak pemasangan maupun posisi dari tepi elemen beton. Posisi dari tepi elemen beton inilah yang dinamakan tebal selimut beton. Pengukuran yang dilakukan ini menggunakan alat bantu dari PROCEQ yaitu Profometer S.
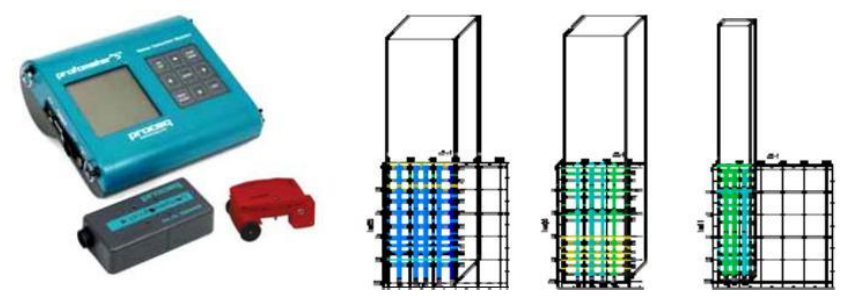

Gambar 4. Alat Rebar Detector tipe Proceq Profometer S dan contoh aplikasinya pada kolom

\subsection{Kondisi Potensial Korosi Beton}

Pengukuran nilai potensial terjadinya korosi menggunakan metode pengukuran nilai half cell potential dari tulangan yang terpasang. Dalam metode ini pengukuran berdasarkan nilai potensial yang terjadi pada permukaan beton yang dihubungkan dengan kondisi korosi baja yang terdapat di dalam beton. Dan pengukuran menggunakan alat bantu CANIN+ Corrosion Analyser. Yang mana pada dasarnya alat ini mengukur perbedaan nilai half cell potential pada permukaan beton dengan elektroda standard adalah Cupri Sulfat (CuSO4).
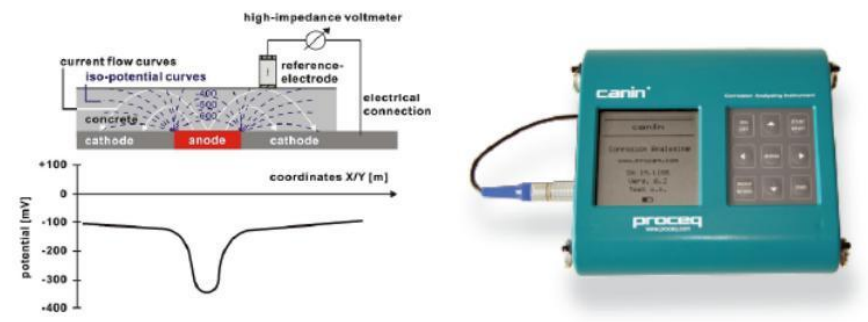

Gambar 5. Metode Pengukuran Half Cell Potential dan Alat CANIN+

Tabel 1. Hubungan Nilai Potensial Tulangan dengan Kemungkinan Korosi pada Tulangan Sesuai ASTM C.876

\begin{tabular}{|c|c|}
\hline Nilai Potensial & Kondisi Tulangan \\
\hline$>-200 \mathrm{mV}$ & Kemungkinan korosi $<10 \%$ \\
\hline$-200 \mathrm{mV} \mathrm{s} / \mathrm{d}-350 \mathrm{mV}$ & Korosi tidak menentu $( \pm 50 \%)$ \\
\hline$<-350 \mathrm{mV}$ & Tingkat korosi bisa mencapai $90 \%$ \\
\hline
\end{tabular}

\subsection{Analisa Struktur dengan Beban Gempa sesuai SNI 1726-2012}

Peninjauan beban gempa pada perencanaan struktur bangunan ini ditinjau secara analisa dinamis 3 dimensi. Fungsi response spectrum ditetapkan sesuai peta wilayah gempa untuk daerah Surabaya-Jawa Timur. Berdasarkan SNI 17262012, zonasi peta gempa menggunakan peta gempa untuk probabilitas $2 \%$ terlampaui dalam 50 tahun atau memiliki periode ulang 2500 tahun.

Untuk wilayah gempa berdasarkan SNI 1726-2012 pasal 14, ditetapkan berdasarkan parameter S (percepatan batuan dasar pada periode pendek 0.2 detik) dan $S_{1}$ (percepatan batuan dasar pada peride 1 detik). Faktor keutamaan dari gedung ini yang merupakan bangunan hunian memiliki faktor keutamaan gempa (Ie) 1, karena sesuai tabel 1 SNI 1726-2012 bangunan gedung apartemen termasuk dalam kategori resiko II. Respons spektral merupakan konsep pendekatan yang digunakan untuk keperluan perencanaan bangunan tahan gempa. Respons spektral menggambarkan respon maksimum dari suatu sistem Single Degree of Freedom (SDOF) baik berupa percepatan (a), kecepatan (v) maupun perpindahan (d) untuk periode natural tertentu akibat beban gempa. Besaran gaya gempa merujuk pada persamaan pada SNI 1726-2012 adalah :

$V=C_{S} \cdot W_{t}$

Dimana :

$\mathrm{C}_{\mathrm{s}}=$ koefisien respons seismik

$\mathrm{W}_{\mathrm{t}}=$ berat total gedung 


\section{Kontrol Periode Alami Struktur}

Nilai T (waktu getar alami struktur) dibatasi oleh waktu getar alami fundamental untuk mencegah penggunaan struktur yang terlalu fleksibel dengan perumusan dalam SNI 1726-2012 sebesar :

$T_{a}=C_{t} \cdot h_{n}^{x}$

Dimana :

$\mathrm{hn}=$ ketinggian struktur $(103 \mathrm{~m})$

$\mathrm{Ct}=$ parameter pendekatan tipe struktur (rangka beton pemikul momen sebesar 0.0466) $\mathrm{x}=$ parameter pendekatan tipe struktur (rangka beton pemikul momen sebesar 0.9)

Tabel 2. Nilai Parameter Perioda Pendekatan $C_{t}$ dan x (SNI 1726-2012, Tabel 14)

\begin{tabular}{|l|c|c|}
\hline \multicolumn{1}{|c|}{ Tipe struktur } & $C_{t}$ & $X$ \\
\hline $\begin{array}{l}\text { Sistem rangka pemikul momen di mana rangka memikul } 100 \text { persen gaya } \\
\text { gempa yang disyaratkan dan tidak dilingkupi atau dihubungkan dengan } \\
\text { komponen yang lebih kaku dan akan mencegah rangka dari defleksi jika } \\
\text { dikenai gaya gempa: }\end{array}$ & & \\
\hline Rangka baja pemikul momen & $0,0724^{\circ}$ & 0,8 \\
\hline Rangka beton pemikul momen & $0,0466^{\circ}$ & 0,9 \\
\hline Rangka baja dengan bresing eksentris & $0,0731^{\circ}$ & 0,75 \\
\hline Rangka baja dengan bresing terkekang terhadap tekuk & $0,0731^{a}$ & 0,75 \\
\hline Semua sistem struktur lainnya & $0,0488^{\alpha}$ & 0,75 \\
\hline
\end{tabular}

Tabel 3. Koefisien untuk Batas Atas pada Perioda yang Dihitung (SNI 1726-2012, Tabel 15)

\begin{tabular}{|c|c|}
\hline $\begin{array}{c}\text { Parameter percepatan respons } \\
\text { spektral desain pada } \mathbf{1} \text { detik, } \boldsymbol{S}_{\boldsymbol{D} 1}\end{array}$ & Koefisien $\boldsymbol{C}_{\boldsymbol{u}}$ \\
\hline$\geq 0,4$ & 1,4 \\
\hline 0,3 & 1,4 \\
\hline 0,2 & 1,5 \\
\hline 0,15 & 1,6 \\
\hline$\leq 0,1$ & 1,7 \\
\hline
\end{tabular}

dengan batas atas perioda fundamental struktur sebesar, $T_{a \text { atas }}=C_{u} \cdot T_{a}$

\section{Kontrol Simpangan Antar Lantai}

Simpangan antar lantai $(\Delta)$, akibat gempa yang ditinjau dengan analisa elastis, yang ditunjukkan oleh gambar 6 tidak boleh melebihi simpangan antar lantai tingkat ijin $\left(\Delta_{\mathrm{a}}\right)$.

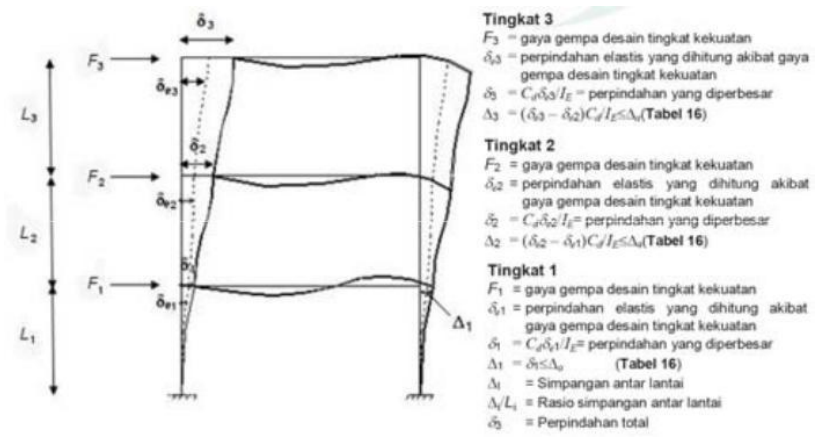

Gambar 6. Penentuan Simpangan antar Lantai

Tabel 4. Simpangan Ijin antar Lantai, a (SNI 1726-2012, Tabel 16)

\begin{tabular}{|c|c|c|c|}
\hline \multirow{2}{*}{ Struktur } & \multicolumn{3}{|c|}{ Kategori risiko } \\
\hline & I atau II & III & IV \\
\hline $\begin{array}{l}\text { Struktur, selain dari struktur dinding geser batu bata, } 4 \text { tingkat } \\
\text { atau kurang dengan dinding interior, partisi, langit-langit dan } \\
\text { sistem dinding eksterior yang telah didesain untuk } \\
\text { mengakomodasi simpangan antar lantai tingkat. }\end{array}$ & $0,025 h_{s x}{ }^{c}$ & $0,020 h_{s x}$ & $0,015 h_{x}$ \\
\hline Struktur dinding geser kantilever batu bata ${ }^{\alpha}$ & $0,010 h_{\mathrm{si}}$ & $0,010 h_{s}$ & $0,010 h_{s}$ \\
\hline Struktur dinding geser batu bata lainnya & $0,007 h_{\mathrm{m}}$ & $0,007 h_{s x}$ & $0,007 h_{x}$ \\
\hline Semua struktur lainnya & $0,020 h_{s x}$ & $0,015 h_{s x}$ & $0,010 h_{\text {st }}$ \\
\hline
\end{tabular}

\section{METODE PENELITIAN}


Metode penelitian tentang evaluasi kelayakan struktur gedung tinggi yang terbengkalai selama 15 tahun terhadap gempa berdasarkan SNI 17262012 ini secara garis besar adalah sebagai berikut :

- Tahapan Persiapan

1. Menyusun pendekatan dan metodologi.

2. Pengumpulan Data Sekunder

- Survey dan Pengujian Material Beton Bertulang, meliputi :

a. Pengambilan sample beton (benda uji) dengan core drill, dilakukan berdasarkan ASTM C42-90.

b. Pengujian kemungkinan korosi pada Beton dengan Halfcell Potential Test sesuai dengan ASTM C 876.

c. Pengujian kualitas kepadatan beton dengan Ultrasonic Pulse Velocity Test (UPV Test) sesuai dengan ASTM C 597.

d. Pengukuran tebal selimut beton dan jumlah baja tulangan dengan Rebar Detector Test sesuai dengan SNI 2847 2013.

e. Pengujian kekuatan tekan beton terhadap benda uji core drill, sesuai persyaratan ASTM C39-93A.

- Tahap Analisa

Analisa data terhadap evaluasi kondisi struktur gedung tinggi yang terbengkalai selama 15 tahun terhadap gempa berdasarkan SNI 1726 2012, meliputi beberapa hal sebagai berikut :

1. Analisis dan evaluasi mutu kekuatan tekan beton dan mutu tarik baja dari hasil-hasil pengujian beton, baik dari hasil test non-destruktif maupun destruktif.

2. Analisa struktur dilakukan untuk mengetahui performa terkini dari gedung tersebut berdasarkan dari observasi yang telah dilakukan di lapangan.

3. Verifikasi strukur dilakukan dengan membuat pemodelan bangunan secara menyeluruh sesuai dengan data gambar exsisting dan hasil penyelidikan struktur. Model stuktur tersebut kemudian disimulasikan terhadap beban rencana (termasuk beban gempa) dan diteliti perilakunya.

- Kesimpulan

\section{HASIL DAN PEMBAHASAN}

\subsection{Hasil Pengujian Struktur di Lapangan dan Laboratorium}

- Hasil pengujian kuat tekan di laboratorium mendapatkan luaran kuat tekan dari sampel silinder beton (CD $1 \mathrm{~s} / \mathrm{d}$ CD 6). Kuat tekan rata-rata adalah sebesar $=313,94 \mathrm{~kg} / \mathrm{cm}^{2}$. Sedangkan nilai kuat tekan minimum terjadi pada sampel CD 4 dengan $\min =303,24 \mathrm{~kg} / \mathrm{cm}^{2}$.

- Hasil klasifikasi beton berdasarkan nilai rata - rata pengujian UPV pada Gedung Crystal Garden menunjukkan bahwa kepadatan beton aktual bangunan masih masuk dalam kategori "Cukup Baik".

- Pengujian rebar detector dilakukan pada gedung Crystal Garden dengan tujuan untuk mengetahui penulangan dari elemen struktur yang ditinjau, sehingga selanjutnya dapat digunakan sebagai dasar dalam evaluasi kelayakan struktur.

- Hasil pengujian potensial korosi menunjukkan bahwa pada elemen struktur pelat, balok dan kolom Gedung Crystal Garden ini rata - rata nilainya adalah sebesar : $-87,33 \mathrm{mV}$. Jika kemudian dihubungkan dengan Tabel Hubungan Nilai Potensial Tulangan dengan Kemungkinan Korosi pada Tulangan sesuai ASTM C.876, maka elemen struktur pada Gedung Crystal Garden ini masih dalam kategori kemungkinan korosi $<10 \%$.

Tabel 5. Penulangan Elemen Struktur Hasil Rebar Detector Test

\begin{tabular}{|c|c|c|c|c|c|c|c|}
\hline \multirow{2}{*}{ Item } & \multirow{2}{*}{ Dimensi (mm) } & \multicolumn{3}{|c|}{ Tulangan Longitudinal } & \multicolumn{2}{|c|}{ Tulangan Tranversal } & \multirow{2}{*}{ Tulangan Torsi } \\
\hline & & Lokasi & Tumpuan & Lapangan & Lapangan & Tumpuan & \\
\hline \multirow[t]{2}{*}{ BU1 } & $300 \times 800$ & Atas & $5 \mathrm{D} 25$ & $4 \mathrm{D} 25$ & $\varphi 8-100$ & $\varphi 8-150$ & $4 \varphi 10$ \\
\hline & & Bawah & $4 \mathrm{D} 25$ & $4 \mathrm{D} 25$ & & & \\
\hline \multirow[t]{2}{*}{ BU2 } & $300 \times 800$ & Atas & $5 \mathrm{D} 25$ & $3 \mathrm{D} 25$ & $\varphi 8-100$ & $\varphi 8-150$ & $4 \varphi 10$ \\
\hline & & Bawah & $3 \mathrm{D} 25$ & $5 \mathrm{D} 25$ & & & \\
\hline \multirow[t]{2}{*}{ BA } & $200 \times 400$ & Atas & $3 \mathrm{D} 22$ & $2 \mathrm{D} 22$ & $\varphi 8-100$ & $\varphi 8-150$ & - \\
\hline & & Bawah & $2 \mathrm{D} 22$ & $3 \mathrm{D} 22$ & & & \\
\hline $\mathrm{K} 1$ & $\varnothing 1300$ & & $112 \mathrm{D} 25$ & & D16 - 100 & & \\
\hline $\mathrm{K} 2 \& \mathrm{~K} 3$ & $\varnothing 1300$ & & $45 \mathrm{D} 25$ & & $\mathrm{D} 13-100$ & & \\
\hline K4 & $\varnothing 1000$ & & $46 \mathrm{D} 22$ & & D13 - 100 & & \\
\hline $\mathrm{S} 1$ & 150 & & $\varphi 16-100$ & & & & \\
\hline SW1A-B & 350 & & D25 - 300 & & $\varphi 10-100$ & & \\
\hline
\end{tabular}

\subsection{Hasil Analisa Struktur}

Analisa struktur dilakukan untuk mengevaluasi performa eksisting gedung Crystal Garden. Perhitungan kekuatan penampang akan dilakukan dengan kekuatan material aktual dan dibandingkan dengan hasil gaya-gaya dalam pada analisa struktur. Mutu beton yang dipakai dalam analisa kali ini adalah 303,24 kg/ $\mathrm{cm}^{2}$. Sedangkan mutu tulangan baja yang dipakai adalah $320 \mathrm{~N} / \mathrm{mm}^{2}$ untuk tulangan polos dan $400 \mathrm{~N} / \mathrm{mm}^{2}$ untuk tulangan ulir. 
Permodelan beban yang diberikan meliputi beban mati, beban hidup, beban gempa dan beban angin. Beban gempa dimodelkan dengan analisa respons spectrum. Susunan kombinasi beban mengikuti SNI-2847-2013.

Pada evaluasi kapasitas penampang, stuktur gedung Crystal Garden diasumsikan sebagai struktur rangka pemikul momen khusus. Sehingga perhitungan analisa kapasitas penampang mengikuti persyaratan dari pasal 21.5 SNI-2847-2013. Tabel 6 dan 7 menunjukkan analisa penampang pada elemen struktur balok dan kolom. Kuat nominal momen $M_{n}$ dihitung bedasarkan ekuivalen stress block dari SNI-2847-2013. Perhitungan tersebut menggunakan kekuatan material aktual. Angka rasio lebih dari 1 menunjukkan bahwa kapasitas penampang lebih kecil dari beban yang bekerja.

Tabel 6. Hasil analisa penampang balok

\begin{tabular}{|l|c|c|c|c|c|c|}
\hline Balok & $\begin{array}{c}\varnothing \mathrm{M}_{\mathrm{n}} \\
\mathrm{kNm}\end{array}$ & $\begin{array}{c}\mathrm{M}_{\mathrm{u}} \\
\mathrm{kNm}\end{array}$ & $\varnothing \mathrm{M}_{\mathrm{n}} / \mathrm{M}_{\mathrm{u}}$ & $\begin{array}{c}\varnothing \mathrm{V}_{\mathrm{n}} \\
\mathrm{kN}\end{array}$ & $\begin{array}{c}\mathrm{V}_{\mathrm{u}} \\
\mathrm{kN}\end{array}$ & $\varnothing \mathrm{V}_{\mathrm{n}} / \mathrm{V}_{\mathrm{u}}$ \\
\hline BU1 & 1136 & 529 & 2.15 & 471 & 403 & 1.17 \\
\hline BU2 & 1136 & 542 & 2.10 & 471 & 470 & 1.00 \\
\hline
\end{tabular}

Tabel 7. Hasil analisa penampang kolom

\begin{tabular}{|c|c|c|c|c|c|c|}
\hline Item & $\begin{array}{c}\varnothing \mathrm{P}_{\mathrm{n}} \\
\mathrm{kNm}\end{array}$ & $\begin{array}{c}\mathrm{Pu}_{\mathrm{u}} \\
\mathrm{kNm}\end{array}$ & $\varnothing \mathrm{P}_{\mathrm{n}} / \mathrm{P}_{\mathrm{u}}$ & $\begin{array}{c}\varnothing \mathrm{V}_{\mathrm{n}} \\
\mathrm{kN}\end{array}$ & $\begin{array}{r}\mathrm{V}_{\mathrm{u}} \\
\mathrm{kN} \\
\end{array}$ & $\varnothing \mathrm{V}_{\mathrm{n}} / \mathrm{V}_{\mathrm{u}}$ \\
\hline K1 & 28427 & 26538 & 1.07 & 2470 & 334 & 7.39 \\
\hline $\mathrm{K} 2 \& \mathrm{~K} 3$ & 27272 & 22349 & 1.22 & 2173 & 334 & 6.50 \\
\hline
\end{tabular}

Dari tabel tersebut ditunjukkan bahwa kapasitas nominal balok untuk lentur dan geser BU1, BU2 dan BA lebih besar daripada beban yang bekerja. Meskipun telah dimasukkan parameter kombinasi beban gempa menurut SNI 17262012 , masih didapatkan rasio kapasitas lentur balok maupun gesernya lebih dari 1. Sedangkan rasio kapasitas aksial, lentur dan geser kolom K1, K2 \& K3 juga memiliki nilai lebih dari 1 yang menujukkan bahwa kapasitas aksial, lentur dan geser kolom lebih besar dari gaya-gaya yang bekerja pada kolom tersebut.

Respons dinamik dari gedung Crystal Garden ini juga ditinjau menurut persyaratan yang ada dalam SNI 17262012. Kontrol yang pertama adalah periode alami struktur, dengan permodelan SAP2000 didapatkan periode alami gedung adalah sebesar 3.682 detik dan nilai tersebut masih dibawah batas atas periode alami gedung yang diijinkan oleh SNI 1726-2012 yaitu sebesar 4,23 detik. Kedua adalah kontrol simpangan antar lantai didapatkan simpangan antar yang terjadi masih dibawah simpangan maksimal yang diijinkan oleh SNI 1726-2012 baik arah x maupun arah y.

Tabel 8. Hasil kontrol simpangan antar lantai arah $\mathrm{x}$ dan y gedung.

\begin{tabular}{|c|c|c|c|c|c|c|c|c|c|c|c|c|c|c|c|}
\hline Lantai & $\begin{array}{c}\text { Elevasi } \\
\text { (m) }\end{array}$ & $\begin{array}{l}\text { Tinggi } \\
\text { antar } \\
\text { tingkat } \\
\text { (m) }\end{array}$ & $\begin{array}{c}\delta \mathrm{e} \\
(\mathrm{mm})\end{array}$ & $\begin{array}{c}\delta \mathrm{xe} \\
(\mathrm{mm})\end{array}$ & $\begin{array}{c}\delta \mathrm{x} \\
(\mathrm{mm})\end{array}$ & $\begin{array}{c}\delta \mathrm{a} \\
(\mathrm{mm})\end{array}$ & KET & Lantai & $\begin{array}{c}\text { Elevasi } \\
(\mathrm{m})\end{array}$ & $\begin{array}{l}\text { Tinggi } \\
\text { antar } \\
\text { tingkat } \\
\text { (m) }\end{array}$ & $\begin{array}{c}\delta \mathrm{e} \\
(\mathbf{m m})\end{array}$ & $\begin{array}{c}\delta \mathrm{xe} \\
(\mathrm{mm})\end{array}$ & $\begin{array}{c}\delta \mathrm{x} \\
(\mathrm{mm})\end{array}$ & $\begin{array}{c}\delta \mathrm{a} \\
(\mathrm{mm})\end{array}$ & KET \\
\hline Lantai 25 & 100.00 & 4.00 & \begin{tabular}{|l|l|}
184 \\
\end{tabular} & \begin{tabular}{|l|}
7.77 \\
\end{tabular} & 42.76 & 80 & $O K$ & Lantai 25 & 100.00 & 4.00 & 212.1 & 1.08 & 5.96 & 80 & $O K$ \\
\hline Lantai 24 & 96.00 & 4.00 & 176.2 & 5.47 & 30.11 & 80 & $O K$ & Lantai 24 & 96.00 & 4.00 & 211 & 7.02 & 38.60 & 80 & $O K$ \\
\hline Lantai 23 & 92.00 & 4.00 & \begin{tabular}{|l|}
170.8 \\
\end{tabular} & 7.06 & 38.85 & 80 & $O K$ & Lantai 23 & 92.00 & 4.00 & 204 & 7.20 & 39.60 & 80 & $O K$ \\
\hline Lantai 22 & 88.00 & 4.00 & 163.7 & 7.27 & 40.00 & 80 & $O K$ & Lantai 22 & 88.00 & 4.00 & 196.8 & 7.48 & 41.13 & 80 & $O K$ \\
\hline Lantai 21 & 84.00 & 4.00 & \begin{tabular}{|l|l|}
156.4 \\
\end{tabular} & 7.45 & 41.00 & 80 & $O K$ & Lantai 21 & 84.00 & 4.00 & 189.3 & 7.78 & 42.81 & 80 & $O K$ \\
\hline Lantai 20 & 80.00 & 4.00 & \begin{tabular}{|l|}
149 \\
\end{tabular} & 7.67 & 42.21 & 80 & $O K$ & Lantai 20 & 80.00 & 4.00 & 181.6 & 8.15 & 44.81 & 80 & $O K$ \\
\hline Lantai 19 & 76.00 & 4.00 & \begin{tabular}{|l|}
141.3 \\
\end{tabular} & 7.93 & 43.59 & 80 & $O K$ & Lantai 19 & 76.00 & 4.00 & 173.4 & 8.55 & 447.03 & 80 & $O K$ \\
\hline Lantai 18 & 72.00 & 4.00 & \begin{tabular}{|l|}
133.4 \\
\end{tabular} & 8.19 & 45.06 & 80 & $O K$ & Lantai 18 & 72.00 & 4.00 & 164.9 & 8.97 & 49.35 & 80 & $O K$ \\
\hline Lantai 17 & 68.00 & 4.00 & 125.2 & 8.46 & 46.56 & 80 & $O K$ & Lantai 17 & 68.00 & 4.00 & 155.9 & 9.39 & 51.65 & 80 & $O K$ \\
\hline Lantai 16 & 64.00 & 4.00 & \begin{tabular}{|l|}
116.7 \\
\end{tabular} & 8.81 & 48.44 & 80 & $O K$ & Lantai 16 & 64.00 & 4.00 & 146.5 & 9.85 & 54.17 & 80 & $O K$ \\
\hline Lantai 15 & 60.00 & 4.00 & \begin{tabular}{|l|}
107.9 \\
\end{tabular} & 8.92 & 49.06 & 80 & $O K$ & Lantai 15 & 60.00 & 4.00 & 136.7 & 10.12 & 55.65 & 80 & $O K$ \\
\hline Lantai 14 & 56.00 & 4.00 & 98.99 & 9.09 & 50.01 & 80 & $O K$ & Lantai 14 & 56.00 & 4.00 & 126.5 & 10.43 & 57.38 & 80 & $O K$ \\
\hline Lantai 13 & 52.00 & 4.00 & \begin{tabular}{|l|}
89.9 \\
\end{tabular} & 9.27 & 50.98 & 80 & $O K$ & Lantai 13 & 52.00 & 4.00 & 116.1 & 10.66 & 58.60 & 80 & $O K$ \\
\hline Lantai 12 & 48.00 & 4.00 & 80.63 & 9.00 & 49.49 & 80 & $O K$ & Lantai 12 & 48.00 & 4.00 & 105.4 & 10.78 & 59.30 & 80 & $O K$ \\
\hline Lantai 11 & 44.00 & 4.00 & 71.63 & 8.91 & 49.01 & 80 & $O K$ & Lantai 11 & 44.00 & 4.00 & 94.67 & 10.81 & 59.46 & 80 & $O K$ \\
\hline Lantai 10 & 40.00 & 4.00 & 62.72 & 8.65 & 447.58 & 80 & $O K$ & Lantai 10 & 40.00 & 4.00 & 83.86 & 10.74 & 59.05 & 80 & $O K$ \\
\hline Lantai 9 & 36.00 & 4.00 & 54.07 & 8.12 & 44.66 & 80 & $O K$ & Lantai 9 & 36.00 & 4.00 & 73.12 & 10.49 & 57.69 & 80 & $O K$ \\
\hline Lantai 8 & 32.00 & 4.00 & 45.95 & 7.55 & 41.52 & 80 & $O K$ & \begin{tabular}{|l} 
Lantai 8 \\
\end{tabular} & 32.00 & 4.00 & 62.63 & 11.78 & 64.79 & 80 & $O K$ \\
\hline Lantai 7 & 28.00 & 4.00 & \begin{tabular}{|l|}
38.4 \\
\end{tabular} & 6.35 & 34.91 & 80 & $O K$ & \begin{tabular}{|l} 
Lantai 7 \\
\end{tabular} & 28.00 & 4.00 & 50.85 & $\begin{array}{l}9.19 \\
\end{array}$ & 50.56 & 80 & $O K$ \\
\hline Lantai 6 & 24.00 & 4.00 & 32.05 & 5.78 & 31.81 & 80 & $O K$ & \begin{tabular}{|l} 
Lantai 6 \\
\end{tabular} & 24.00 & 4.00 & 41.66 & 4.86 & 26.75 & 80 & $O K$ \\
\hline Lantai 5 & 20.00 & 4.00 & 26.27 & 5.68 & 31.25 & 80 & $O K$ & Lantai 5 & 20.00 & 4.00 & 36.79 & 5.91 & 32.48 & 80 & $O K$ \\
\hline Lantai 4 & 16.00 & 4.00 & 20.59 & 5.55 & 30.54 & 80 & $O K$ & \begin{tabular}{|l|} 
Lantai 4 \\
\end{tabular} & 16.00 & 4.00 & 30.89 & 6.80 & 37.37 & 80 & $O K$ \\
\hline Lantai 3 & 12.00 & 4.00 & 15.04 & 5.24 & 28.80 & 80 & $O K$ & \begin{tabular}{|l|} 
Lantai 3 \\
\end{tabular} & 12.00 & 4.00 & 24.09 & 7.47 & 41.11 & 80 & $O K$ \\
\hline Lantai 2 & 8.00 & 4.00 & 9.799 & 4.82 & 26.49 & 80 & $O K$ & \begin{tabular}{|l|} 
Lantai 2 \\
\end{tabular} & 8.00 & 4.00 & 16.62 & 7.77 & 42.75 & 80 & $O K$ \\
\hline Lantai Mez & 4.00 & 4.00 & 4.983 & 3.80 & 20.91 & 80 & $O K$ & Lantai Mez & 4.00 & 4.00 & 8.843 & 6.69 & 36.79 & 80 & $O K$ \\
\hline Lantai 1 & 0.00 & 3.00 & 1.18 & 1.18 & \begin{tabular}{|l|}
6.49 \\
\end{tabular} & 60 & $O K$ & \begin{tabular}{|l|} 
Lantai 1 \\
\end{tabular} & 0.00 & 3.00 & 2.153 & 2.15 & 11.84 & 60 & $O K$ \\
\hline Lantai BS & -3.00 & 3.00 & 0.00 & 0.00 & 0.00 & 60 & $O K$ & Lantai BS & -3.00 & 3.00 & 0.00 & 0.00 & 0.00 & 60 & $O K$ \\
\hline
\end{tabular}

\section{KESIMPULAN}

Evaluasi kelayakan gedung yang terbengkalai 15 tahun pada gedung Crystal Garden yang dianalisa dan dievaluasi menggunakan gempa sesuai SNI 17262012 memberikan beberapa kesimpulan sebagai berikut : 
1. Gedung tinggi pada umumnya telah dirancang dengan mutu material yang tinggi sehingga meskipun terbengkalai selama 15 tahun lebih, dari sisi mutu material dan potensi korosi masih menunjukkan performa yang baik.

2. Gedung tinggi umumnya juga telah dirancang dengan dimensi dan penulangan elemen struktur yang memiliki faktor keamanan cukup tinggi. Sehingga walaupun ditinjau menggunakan pembebanan gempa sesuai SNI 17262012 , struktur masih menunjukkan respon yang cukup baik dan layak untuk difungsikan kembali sebagai hunian dan pusat perbelanjaan.

3. Selain faktor perancangan yang ketat, faktor pelaksanaan pembangunan juga memiliki pengaruh yang signifikan dalam keawetan bangunan. Hal ini dapat terukur dari tingkat kepadatan beton yang baik dan selimut beton yang terpasang sesuai peraturan yang berlaku.

\section{DAFTAR PUSTAKA}

[1] H. CHRISTIAWAN, I., TRIWIYONO, A., AND CHRISTADY, "Evaluasi Kinerja dan Perkuatan Struktur Gedung Guna Alih Fungsi Bangunan,” Forum Tek. Sipil, vol. 17, pp. 725-738, 2008.

[2] M. S. HUSIN, N. A., AND DARMAWAN, "Evaluasi Struktur Gedung Bank Papua Cabang Manokwari Pasca Gempa," in $A T P W, 2008$, pp. 62-71.

[3] D. MADUTUJUH, N., PRAWIRANEGARA, J., ARIADI, AND NATALIUS, “Audit Kekuatan Struktur dan Perkuatan Struktur Pasca Gempa,” in HASTAG, 2013.

[4] F. MARSIANO, AND SETIAWAN, "Evaluasi Struktur Gedung Head Office PT. TMMN.," Saintech, vol. 19, pp. 16-21, 2009.

[5] T. WINARSIH, “Asesmen Kekuatan Struktur Bangunan Gedung,” Universitas Sebelas Maret, 2010. 